\title{
THE SPECIFICITY OF RABBIT ANTISERA TO HERPES- VIRUS HOMINIS AND ITS DEPENDENCE ON THE DOSE OF VIRUS INOCULATED
}

\author{
J. F. Peutherer \\ Department of Bacteriology, University of Edinburgh
}

THE quantal neutralisation test of Fazekas de St. Groth (1961) was applied by Pauls and Dowdle (1967) to distinguish between strains of Herpesvirus hominis. The application depended on the development of tissue culture micro-techniques and utilised primary rabbit kidney tissue cells. The present paper demonstrates that BHK21 cells (Macpherson and Stoker, 1962) can also be used in this procedure. During the study it was found, in contrast to the findings of Pauls and Dowdle, that rabbit antisera to type-1 virus cross-reacted strongly with type-2 virus, whereas antisera to type-2 virus showed a less marked cross-reaction. An investigation into the effect of varying the dose of virus given to the rabbits to produce the antisera provided a possible explanation for the discrepancy.

\section{MATERIALS AND METHODS}

Virus strain MS obtained from Dr G. Plummer was taken as a representative type-2 virus (Plummer, 1964; Pauls and Dowdle); strain HF obtained from the Institute of Virology, Glasgow, was taken as a representative type-1 virus (Pauls and Dowdle); strain 1657 isolated in Edinburgh has been used in the preparation of complement-fixing and neutralising antigens in this laboratory (Smith, Peutherer and MacCallum, 1967). In addition to these three strains, the Watson and Dawson strains of Herpesvirus hominis, previously reported as being type-1 and type-2 strains respectively (Plummer, Waner and Bowling, 1968), were obtained from Dr Plummer. Rabbits were given inoculations of virus strains MS, HF and 1657 produced in RK13 cells grown at $35^{\circ} \mathrm{C}$ in 1-litre Roux flasks containing $100 \mathrm{ml}$ of medium 199 supplemented with 5 per cent. rabbit serum. Cells showing an almost complete cytopathic effect (CPE) after 1-2 days were harvested with glass beads in $40 \mathrm{ml}$ medium per Roux flask. Before use, these cell suspensions were frozen and thawed three times and treated for $5 \mathrm{~min}$. at full power in a Kerry ultrasonic bath. These stocks were titrated for infectivity as described below in BHK21 cells. Extracts from uninfected cells were prepared in the same way. Antisera were produced in rabbits of the department stock according to the schedule of Plummer. Intramuscular and intraperitoneal injections of $3 \mathrm{ml}$ of virus suspension without adjuvant were given initially and repeated $3 \mathrm{wk}$ later. One week after the second inoculation, the rabbits were bled out. Pairs of rabbits were immunised with suspensions of each of the three viruses HF, MS and 1657 containing $10^{3.5}-10^{5.8}$ TCID50 per $0.02 \mathrm{ml}$ to produce " high-dose" $(\mathrm{H})$ sera. In addition, pairs of rabbits were given inoculations of the above virus stocks diluted to contain $10^{1 \cdot 5}-102 \cdot 5$ TCID50 per $0.02 \mathrm{ml}$ to produce "low-dose" (L) sera.

Stock virus for neutralisation tests was grown in BHK21 cells in diploid cell medium (Grand Island Biological Corporation, Grand Island, New York) supplemented as described by Peutherer and Smith (1966), in rolling 2-litre culture bottles (House and Wildy, 1965). Cells were harvested as above in $20 \mathrm{ml}$ medium per bottle and treated at full power for

Received 1 July 1969; accepted 20 Oct. 1969.

J. MED. MICROBIOL.—VOL. 3 (1970) 
$5 \mathrm{~min}$. in an MSE ultrasonicator. After centrifugation at $400 \mathrm{~g}$ for $10 \mathrm{~min}$., the supernate was stored in small volumes at $-65^{\circ} \mathrm{C}$.

Both infectivity and neutralising antibody titrations were performed according to the methods of Pauls and Dowdle in "Linbro" plastic disposable plates (ISFB96), with BHK21 cells at a concentration of 500,000 cells per $\mathrm{ml}$. Pipettes were drawn from glass tubing and calibrated with a wire gauge to a diameter that delivered drops of $0.02 \mathrm{ml}$. A separate dropping pipette was used for each serum dilution in the neutralising antibody estimation. Plates were sealed with clear adhesive tape and incubated for 3 days at $35^{\circ} \mathrm{C}$, after which each well was examined with an inverted microscope. Wells showing 5 per cent. or more of CPE were scored as positive and 50 per cent. end-point dilutions were calculated for both infectivity and neutralising antibody titrations by the method of Reed and Muench (1938). In these calculations, for example, a dilution of 1 in 10 was expressed as $1 / 10$, or $10^{-1}$, and the 50 per cent. end-point dilutions in the same manner.

\section{TABLE I}

Serum neutralisation titres and $p N$ values of an $H F-H$ serum against $H F$ virus used at different concentrations in the neutralisation test

\begin{tabular}{c|c|c}
$\begin{array}{c}\text { Titre of challenge virus } \\
\text { used in test } \\
\text { (log }\end{array}$ & $\begin{array}{c}\text { Log } \\
10 \text { titre of neutralising } \\
\text { antibody in serum }\end{array}$ & pN value \\
\hline $2.02 \mathrm{ml})$ & 2.74 & \\
\hline 2.7 & 2.52 & 2.89 \\
3.0 & 2.31 & 2.94 \\
3.7 & 2.09 & 2.72 \\
4.0 & 2.03 & 2.71 \\
\hline
\end{tabular}

The reciprocal of the end-point dilution of the virus suspension was taken as the infectivity titre (TCID50) and that of the 50 per cent. end-point dilution of the serum as the neutralising antibody titre. The neutralising potency of a serum against a test strain was determined in terms of the serum $\mathrm{pN}$ value calculated from the formula of Pauls and Dowdle. Allowing for the different size of standard drop employed, $\mathrm{pN}=\log (\mathrm{V}-d-1 \cdot 16)+t+0 \cdot 23$, when $V=\log _{10}$ virus control titre, $d=-\log _{10}$ dilution of virus used in neutralisation reaction, and $t=\log _{10}$ serum titre. In some instances, no neutralisation of a virus could be demonstrated even at the highest concentration of serum tested ( 1 in 10 dilution). Based on a neutralisation end-point dilution of 1 in 10, in fact, the minimum calculable value of $\mathrm{pN}$ is 1.49 . To allow average values and $\mathrm{pN}$ differences to be calculated, the $\mathrm{pN}$ values of these sera were scored as " 0 ", instead of " $<1.49$ ".

\section{RESULTS}

The reproducibility of the values for infectivity titres (TCID50) was tested by performing six replicate titrations of a single preparation of MS virus grown in BHK21 cells. The values obtained all fell within the range $10^{5 \cdot 50}-10^{6 \cdot 00}$ TCID50 per $0.02 \mathrm{ml}$, with a mean titre and standard deviation of $105.58 \pm 0.20$ TCID50 per $0.02 \mathrm{ml}$. The effect of varying the dose of virus for use in neutralisation tests on the titre of neutralising antibody and on the resultant $\mathrm{pN}$ value of an anti-HF-H (high dose) serum is shown in table I. Thus, whilst variation of the virus concentration by $\pm 1 \log _{10}$ from the recommended dose of $10^{3.0}$ TCID50 per $0.02 \mathrm{ml}$ gave serum titres ranging from $10^{2.03}$ to $10^{2.74}$, the corresponding $\mathrm{pN}$ values varied only within the narrow range of $2 \cdot 71-2 \cdot 94$. 
A similar experiment with an HF-L serum showed almost identical degrees of variation in the serum titres and $\mathrm{pN}$ values. The reproducibility of the $\mathrm{pN}$ values determined for three sera with the homologous viruses is shown in table II. The standard deviations are comparable to those previously reported (Dowdle et al., 1967). Antisera produced against uninfected cell extracts showed no detectable neutralisation of any of the viruses tested. Table III compares the $\mathrm{pN}$ values obtained for the sera of rabbits given inoculations of high $(\mathrm{H})$ and low $(\mathrm{L})$ concentrations of virus. With 1657-L and MS-L sera the values of less

TABLE II

Reproducibility of $p N$ values obtained in four replicate neutralisation tests made between each of three sera and their homologous viruses

\begin{tabular}{l|c|c|c}
\hline Serum & $\begin{array}{c}\text { pN values in } \\
\text { four tests }\end{array}$ & $\begin{array}{c}\text { Mean pN } \\
\text { value }\end{array}$ & $\begin{array}{c}\text { Standard deviation } \\
\text { of pN values }\end{array}$ \\
\hline $1657-\mathrm{H}$ & 2.68 & 2.64 & \pm 0.07 \\
& 2.57 & & \\
2.70 & & & \\
\hline HF-H & 2.62 & 2.68 & \pm 0.28 \\
& 2.32 & & \\
& 2.84 & & \\
\hline MS-L & 2.87 & 2.58 & \pm 0.20 \\
& 2.55 & & \\
\hline
\end{tabular}

than 1.49 arose because the serum of one of the pair of rabbits did not neutralise the virus tested. Sera produced with the higher immunising doses of virus crossreacted to a considerable degree with heterologous viruses, although in each case the homologous $\mathrm{pN}$ value was greater than the heterologous value. The sera produced with the lower concentrations of immunising virus showed greater specificity and in some cases reacted with homologous virus only. This effect of the concentration of immunising virus may account for the different cross-reactions observed initially in this laboratory compared with the reported findings of Pauls and Dowdle. With the higher doses of virus inoculum, viral antigens will persist in the tissues for a longer period of time, and a hyperimmune antibody response will occur. Under these circumstances, it is accepted that the antisera obtained will show less specificity than those produced with lower concentrations of immunising virus (Boyd, 1956). However, the response of rabbits may be unpredictable because of the ability of Herpesvirus hominis to multiply in the rabbit. Apart from the effect of variation of the dose of immunising virus, one other difference existed between the experimental systems of this report and that of Pauls and Dowdle. These authors used primary rabbit kidney cell cultures both for the production of virus for immunisation of rabbits 
and for the neutralisation reactions. In my study the virus for immunisation was grown in RK13 cells and the virus for neutralising antibody titrations in BHK21 cells. A control antiserum, produced by the inoculation of uninfected RK13 cells, showed no detectable neutralisation of virus grown in BHK21 cells. It cannot be excluded, however, that there may be differences in antibody production according to whether the immunising virus is grown in primary rabbit kidney cells or RK13 cells.

TABLE III

Effect of the size of the dose of virus inoculated into rabbits on the $p N$ value of the resulting antiserum measured against different viruses

\begin{tabular}{|c|c|c|c|c|}
\hline \multirow{2}{*}{ Serun } & \multirow{2}{*}{$\begin{array}{l}\text { Dose of virus } \\
\text { inoculated } \\
\text { into rabbit }\end{array}$} & \multicolumn{3}{|c|}{$\begin{array}{l}\text { pN value * of serum in neutralisation } \\
\text { test with virus of strain }\end{array}$} \\
\hline & & $\underset{\text { (type 1) }}{\mathrm{HF}}$ & $\begin{array}{c}\text { MS } \\
\text { (type 2) }\end{array}$ & $\begin{array}{c}1657 \\
\text { (type 1) }\end{array}$ \\
\hline $\begin{array}{l}\text { HF-H } \\
\text { HF-L }\end{array}$ & $\begin{array}{l}\text { High } \\
\text { Low }\end{array}$ & $\begin{array}{l}2 \cdot 70 \\
1 \cdot 73\end{array}$ & $\begin{array}{c}2 \cdot 43 \\
0\end{array}$ & $\begin{array}{c}2 \cdot 51 \\
0\end{array}$ \\
\hline $\begin{array}{l}\text { MS-H } \\
\text { MS-L }\end{array}$ & $\begin{array}{l}\text { High } \\
\text { Low }\end{array}$ & $\begin{array}{l}2.61 \\
1.08\end{array}$ & $\begin{array}{l}2 \cdot 66 \\
2 \cdot 67\end{array}$ & $\begin{array}{l}2.64 \\
0.90\end{array}$ \\
\hline $\begin{array}{l}1657-\mathrm{H} \\
1657-\mathrm{L}\end{array}$ & $\begin{array}{l}\text { High } \\
\text { Low }\end{array}$ & $\begin{array}{l}2 \cdot 62 \\
0 \cdot 73\end{array}$ & $\begin{array}{c}2 \cdot 42 \\
0\end{array}$ & $\begin{array}{l}2 \cdot 71 \\
1 \cdot 25\end{array}$ \\
\hline
\end{tabular}

* Value shown is the average of the $\mathrm{pN}$ values obtained in two tests made with each of two sera prepared in different rabbits. $\mathrm{pN}$ values obtained in these tests that were less than 1.49 were scored as " 0 " (see Materials and methods). Average values of less than 1.49 shown in the table indicate that one or both of the sera tested gave a value of 0 .

Virus 1657 gave $\mathrm{pN}$ values similar to those of HF and MS viruses when titrated against $\mathrm{H}$ sera. With $\mathrm{L}$ sera, however, it gave results similar to those obtained with HF virus, indicating that 1657 is HF-like, or type 1.

Mixtures prepared for all the neutralisation experiments were kept at room temperature for $\frac{1}{2} \mathrm{hr}$ before inoculation on plates. Incubation of the virus-serum mixture at $37^{\circ}$ or $4^{\circ} \mathrm{C}$ for $\frac{1}{2}$ hr had no appreciable effect on the cross-reactivity of the sera. Incubation for longer periods at room temperature, or at $37^{\circ}$ or $4^{\circ} \mathrm{C}$, did not enhance the specificity of the $\mathrm{pN}$ values; in some cases it increased the degree of cross-reaction.

\section{DisCUSSION}

The modification described above to the method of Pauls and Dowdle (1967) is a reproducible procedure for estimating the infectivity of preparations of Herpesvirus hominis and the virus-neutralising $(\mathrm{pN})$ values of antisera. Compared with the original method, it has the following advantages: $(a)$ the use of a semicontinuous cell system, $\mathrm{BHK} 21$, is less laborious than the preparation of a primary rabbit kidney cell culture, $(b)$ the use of calibrated pasteur pipettes 
avoids the need to purchase or manufacture a large number of permanent standard-drop pipettes, and $(c)$ the incubation time is reduced from 5 to 3 days.

Strains of Herpesvirus hominis can be typed by determining the $\mathrm{pN}$ values with type-1 and type-2 antisera (Dowdle et al., 1967). Values of the difference, $\mathrm{pN} 1$ - pN2, fall into two groups, although the range of values depends on the potency and cross-reactivity of each of the typing sera used. The evidence of the present work indicates that if both of the typing sera show a marked degree of cross-reactivity it may prove difficult to allocate an unknown virus to either type 1 or type 2 . To distinguish between strains of Herpesvirus hominis a pair of antisera, one of greater and one of lower specificity, are used in this laboratory. Table IV illustrates how such a pair of sera can separate a number of strains into

TABLE IV

$p N$ values, $p N$ difference and type of virus determined in neutralisation tests of five strains of virus with an $H F-H$ and an $M S-L$ antiserum

\begin{tabular}{|c|c|c|c|c|}
\hline \multirow{2}{*}{$\begin{array}{l}\text { Virus } \\
\text { strain }\end{array}$} & \multicolumn{2}{|c|}{$\begin{array}{l}\mathrm{pN} \text { value for virus determined } \\
\text { in serum }\end{array}$} & \multirow{2}{*}{$\begin{array}{l}\text { pN difference } \\
(\mathrm{pN} 1-\mathrm{pN} 2)\end{array}$} & \multirow{2}{*}{$\begin{array}{c}\text { Type of virus } \\
\text { indicated } \\
\text { by result }\end{array}$} \\
\hline & $\mathrm{HF}-\mathrm{H}(\mathrm{pN} 1)$ & MS-L (pN2) & & \\
\hline $\begin{array}{l}\mathrm{HF} \\
\mathrm{MS} \\
1657 \\
\text { Watson } \\
\text { Dawson }\end{array}$ & $\begin{array}{l}2 \cdot 68 \\
2 \cdot 32 \\
2 \cdot 41 \\
2 \cdot 40 \\
1 \cdot 95\end{array}$ & $\begin{array}{c}0 \\
2 \cdot 58 \\
0 \\
0 \\
2 \cdot 10\end{array}$ & $\begin{array}{l}+2.68 \\
-0.26 \\
+2.41 \\
+2.40 \\
-0.15\end{array}$ & $\begin{array}{l}1 \\
2 \\
1 \\
1 \\
2\end{array}$ \\
\hline
\end{tabular}

two antigenic types. The type- 1 viruses reacted only with HF antisera and gave a positive value for the difference $\mathrm{pN} 1-\mathrm{pN} 2$. The type- 2 viruses reacted with both antisera and gave a negative value for the difference $\mathrm{pN} 1-\mathrm{pN} 2$. The antigenic typing of strains Dawson and Watson agrees with the reported results of Plummer et al. (1968).

\section{SUMMARY}

Typing of strains of Herpesvirus hominis according to the method of Pauls and Dowdle can be performed in BHK cells instead of in primary rabbit kidney cells. The modified method has the advantage of a reduction in incubation time and the convenience of working with a semi-continuous cell line. The concentration of virus antigen inoculated into rabbits to produce typing antisera has an effect on the cross-reactivity of the sera obtained. Higher immunising doses of virus produce antisera with higher degrees of cross-reactivity than is found in antisera produced in response to low immunising doses of virus.

\section{REFERENCES}

BOYD, W. C.

1956. Fundamentals of immunology, 3rd ed., London and New York, p. 44.

Dowdle, W. R., Nahmias, A. J., HaR- 1967. J. Immun., 99, 974.

Well, R. W., and Pauls, F. P. 
FazeKas De St. Groth, S. . . . . 1961. Nature, Lond., 191, 891.

House, W., AND Wildy, P. . . . . 1965. Lab. Practice, 14, 594.

MACPHERSON, I., AND STOKER, M. . . 1962. Virology, 16, 147.

Pauls, F. P., AND Dowdle, W. R. . . 1967. J. Immun., 98, 941.

Peutherer, J. F., and Smith, Isabel W. 1966. J. Path. Bact., 92, 230.

Plummer, G. . . . . . . . . 1964. Br. J. Exp. Path., 45, 135.

Plummer, G., WANer, J. L., AND 1968. Ibid., 49, 202.

Bowling, C. P.

Reed, L. J., AND Muench, H. . . 1938. Amer. J. Hyg., 27, 493.

Smith, Isabel W., Peutherer, J. F., ANd 1967. J. Hyg., Camb., 65, 395.

MacCallum, F. O. 